\title{
Profil antropometri, ketersediaan energi dan kepadatan tulang pada atlet remaja putri berbagai cabang olahraga
}

\author{
Novi Setyawati, Fillah Fithra Dieny *, Ayu Rahadiyanti, Deny Yudi Fitranti, A. Fahmy Arif Tsani \\ Departemen Ilmu Gizi, Universitas Diponegoro. Jalan Prof. Sudarto No.13, Tembalang, Kec. \\ Tembalang, Kota Semarang, Jawa Tengah 50275, Indonesia \\ * Corresponding Author. Email: fillahdieny@gmail.com
}

Received: 4 April 2020; Revised: 21 April 2020; Accepted: 22 April 2020

\begin{abstract}
Abstrak: Penelitian ini bertujuan untuk menganalisis perbedaan profil antropometri, ketersediaan energi, dan kepadatan tulang pada atlet remaja putri berbagai cabang olahraga. Desain penelitian cross-sectional metode consecutive sampling dengan jumlah 54 atlet usia 13-21 tahun dilaksanakan di BPPLOP Jawa Tengah, Klub Atletik Salatiga, Klub Atletik dan Renang Universitas Negeri Semarang. Persen lemak tubuh, IMT, fat free mass diukur dengan Total Body Composition Analyzer. Form 24 hour-food recall, 24-hour physical activity record dan fat free mass untuk mengukur ketersedian energi. Bone densitometer Osteosys SONOST 3000 untuk mengukur kepadatan tulang. Uji One-way ANOVA dan uji Kruskal Wallis digunakan dalam analisis data. Persen lemak tubuh dan IMT cabang olahraga endurance lebih rendah dibandingkan cabang olahraga kekuatan dan beregu. Terdapat perbedaan ketersediaan energi antara cabang olahraga endurance dan kekuatan $(p<0.05)$. T-score kepadatan tulang cabang olahraga kekuatan lebih rendah dibandingkan cabang olahraga endurance dan beregu. Mayoritas atlet memiliki persen lemak tubuh, IMT, kepadatan tulang tergolong normal, dan ketersediaan energi tergolong rendah.
\end{abstract}

Kata Kunci: Atlet remaja putri, profil antropometri, kepadatan tulang, ketersedian energi, cabang olahraga.

\section{Anthropometric profiles, energy availability and bone density in adolescent Female athletes in various sports}

\begin{abstract}
This study analyzed the differences in anthropometric profile, energy availability, and bone density of adolescent female athletes in various sports. A cross-sectional study design consecutive sampling method with 54 athletes aged 13 -21 years conducted in the BPPLOP Central Java, Salatiga Athletics Club, Athletics, and Swimming Club Semarang State University. Percent body fat, BMI, fat-free mass was measured by Total Body Composition Analyzer. The 24 hour-food recall form, 24-hour physical activity record, and fat-free mass were used for measuring energy availability. Bone densitometer Osteosys SONOST 3000 was used to measure bone density. Data were analyzed by One-way ANOVA and Kruskal Wallis test. Percent body fat and BMI of endurance sports were lower than strength and team sports. There were differences in the energy availability between endurance and strength sports $(p<0.05)$. Bone density $t$-score of strength sports was lower than endurance and team sports. Most athletes classified normal on percent body fat, BMI, and bone density, while energy availability was classified low.
\end{abstract}

Keywords: Adolescent female athletes, anthropometric profile, bone density, energy availability, sports.

How to Cite: Setyawati, N., Dieny, F., Rahadiyanti, A., Fitranti, D., \& Tsani, A. (2020). Profil antropometri, ketersediaan energi dan kepadatan tulang pada atlet remaja putri berbagai cabang olahraga. Jurnal Keolahragaan, 8(1), 21-31. doi:https://doi.org/10.21831/jk.v8i1.30367

\section{PENDAHULUAN}

Kepadatan tulang rendah (osteopenia) merupakan masalah yang dapat dialami perempuan antara lain kelompok remaja putri. Hal ini berkaitan dengan puncak pertumbuhan masa tulang pada perempuan lebih rendah dibandingkan laki-laki. Periode remaja juga terjadi growth spurt merupakan puncak dari pertumbuhan tinggi badan (peak high velocity), dan puncak pertambahan berat badan (peak weight velocity) serta puncak pertumbuhan massa tulang (peak bone mass/PBM) yang menyebabkan kebutuhan gizi pada masa ini lebih tinggi dibandingkan fase kehidupan lainnya (Chapman-Novakofski, 2017). Kepadatan tulang rendah juga terjadi pada atlet khusunya atlet remaja putri. Penelitian di Jepang menye- 
butkan bahwa sebesar 18,6\% atlet remaja putri dengan amenorea memiliki kepadatan tulang rendah (Nose-Ogura et al., 2018). Penelitian di Malaysia yang melibatkan 85 atlet perempuan juga menunjukan bahwa sebanyak 53\% atlet perempuan memiliki kepadatan tulang rendah (Ahmad et al., 2018). Penelitian di Brazil menunjukan sebanyak 17,9\% atlet renang remaja putri memiliki kepadatan tulang rendah (Schtscherbyna et al., 2009).

Olahraga dikelompokan menjadi 3 jenis menurut durasi dan intensitas latihan yaitu olahraga endurance, olahraga kekuatan (strength), dan olahraga power (Muth \& Zive, 2019). Olahraga endurance merupakan jenis olahraga yang dilakukan berkisar 30 menit sampai dengan 4 jam, yang berlangsung lama dan bersifat kontinu, terdiri dari maraton, renang, dayung, lari jarak menengah (Fink \& Mikesky, 2015; Kementerian Kesehatan Republik Indonesia, 2014; Muth \& Zive, 2019). Olahraga kekuatan (strength) merupakan olahraga dengan mengutamakan kekuatan otot dan berlangsung dalam durasi singkat, antara lain dari judo, angkat besi, tinju, lempar lembing, lempar cakram, tolak peluru, binaraga (bodybuilding) (Kementerian Kesehatan Republik Indonesia, 2014; Muth \& Zive, 2019). Olahraga power merupakan olahraga yang dominan pada Gerakan-gerakan yang membutuhkan kekuatan dan kecepatan, berlangsung singkat antara 1 sampai 10 menit serta membutuhkan kekuatan dan daya tahan yang tinggi, terdiri dari cabang olahraga permainan atau beregu (team sports) seperti sepak bola, futsal, bola basket, bola voli, bulu tangkis, tenis lapangan, sepak takraw, dan voli pantai (Muth \& Zive, 2019).

Penelitian menyebutkan bahwa atlet endurance perempuan beresiko mengalami penurunan massa tulang lebih tinggi karena dampak dari jenis, intensitas dan durasi latihan yang tinggi yang akan mempengaruhi status estrogen, tingginya kejadian amenorea, indeks massa tubuh rendah, lemak tubuh rendah dan asupan energi serta kalsium yang tidak adekuat (Braam et al., 2003). Hasil penelitian menunjukan bahwa atlet cabang olahraga endurance (maraton, pelari jarak menengah (800 meter), sepeda, renang) memiliki kepadatan tulang lebih rendah dibandingkan atlet cabang olahraga kekuatan dan beregu (angkat besi, judo, olahraga tim seperti basket, voli, sepak bola, tenis) (Ahmad et al., 2018; Hinrichs et al., 2014). Olahraga kekuatan dan beregu seperti angkat besi, judo dan olahraga tim secara signifikan dapat meningkatkan kepadatan tulang melalui pembebanan kerangka, sedangkan olahraga endurance seperti renang merupakan olahraga tidak menahan beban sehingga tidak ada dampak pembebanan langsung pada kerangka (Bellew \& Gehrig, 2006; Hinrichs et al., 2014; Ito et al., 2016; Mudd et al., 2007).

Ketersediaan energi penting bagi tulang, ketika ketersediaan energi rendah, mekanisme fisiologis akan mengurangi jumlah energi yang digunakan untuk pemeliharaan seluler, termogulasi, pertumbuhan dan reproduksi (Nattiv et al., 2007). Ketersediaan energi rendah biasa terjadi pada atlet endurance, karena atlet mempunyai pengeluaran energi yang tinggi dan seringkali tidak diimbangi dengan asupan yang adekuat karena pembatasan asupan untuk mempertahankan berat badan dengan tujuan meningkatkan performa. Faktor lain yang juga mempengaruhi yaitu gangguan makan dan tidak ada dorongan dari diri atlet untuk menyeimbangkan asupan makan dan pengeluaran energi akibat intensitas latihan yang tinggi (Márquez \& Molinero, 2013). Ketika ketersediaan energi di bawah $30 \mathrm{kkal} / \mathrm{kg}$ FFM maka akan terjadi penurunan fungsi reproduksi dan kepadatan tulang. Resorpsi tulang akan meningkat ketika berolahraga, dengan mengurangi ketersediaan energi untuk menekan estradiol (Anne, 2007). Hasil penelitian menunjukan ketersediaan energi atlet cabang olahraga endurance (lari jarak jauh dan dayung), atlet cabang olahraga kekuatan (sprint) dan cabang olahraga beregu, tergolong rendah (Day et al., 2016; Koehler et al., 2013; Ong \& Brownlee, 2017). Penelitian menyebutkan banyaknya pelari maraton dan atlet endurance lainya mengurangi ketersediaan energi dengan tujuan menurunkan berat badan dan komposisi tubuh untuk meningkatkan performa (Anne, 2007).

Persen lemak tubuh dan indeks massa tubuh menjadi salah satu penentu status gizi pada atlet. Persen lemak tubuh umumnya akan meningkat seiring dengan bertambahnya usia. Jenis kelamin dan cabang olahraga juga mempengaruhi persen lemak pada atlet. Persen lemak tubuh atlet yang berlebih akan mempengaruhi daya tahan, sistem kardiovaskuler, komposisi tubuh seseorang, daya tahan otot dan kelenturan, serta performanya (Amrinanto, 2016). Penelitian pada atlet remaja Ragunan di Jakarta menunjukan rata-rata persen lemak cabang olahraga kekuatan (tolak peluru, sprint dan lompat jauh) berkisar 14-36\% dan cabang olahraga endurance (renang) 21-31\%. Sebanyak 31,6\% atlet atletik cenderung obesitas berdasarkan persen lemak (Amrinanto, 2016). Penelitian lain pada cabang olahraga kekuatan menunjukan semua atlet angkat berat, $77,8 \%$ atlet angkat besi dan $80 \%$ atlet binaraga mengalami obesitas jika dilihat berdasar persen lemak tubuh, sedangkan pada olahraga beregu (voli) tergolong normal (Latni G et al., 2015; Nikolaidis, 2013). Penelitian di Indonesia menunjukan IMT/U pada cabang olahraga kekuatan (atletik) dan cabang olahraga endurance (renang) tergolong normal (Amrinanto, 
2016). Hal ini sejalan dengan penelitian lain bahwa IMT pada cabang olahraga endurance (renang), cabang olahraga kekuatan (pelompat dan sprint) dan cabang olahraga beregu (voli dan voli pantai) juga tergolong normal (Becerra et al., 2018; Carbuhn et al., 2010).

Kepadatan tulang rendah akan menjadi suatu masalah jika terjadi pada kelompok atlet remaja putri. Padahal pada masa remaja seharusnya menjadi masa untuk pengoptimalan cadangan kalsium dan kepadatan tulang yang akan dibutuhkan pada daur kehidupan berikutnya. Rendahnya kepadatan tulang akan berakibat pada osteoporosis di kemudian hari. Ketersediaan energi, IMT dan persen lemak yang rendah juga akan berdampak pada penurunan fungsi reproduksi, kepadatan tulang dan penurunan performa atlet (Márquez \& Molinero, 2013). Berdasarkan hal tersebut dan masih terbatasnya penelitian terkait atlet remaja putri khususnya pada atlet cabang olahraga endurance, kekuatan dan beregu. Oleh karenanya tujuan dari penelitian ini adalah menganalisis perbedaan profil antropometri, ketersediaan energi dan kepadatan tulang pada atlet remaja putri pada berbagai cabang olahraga.

\section{METODE}

Penelitian dilakukan di beberapa lokasi yaitu Balai Pemusatan Pendidikan dan Latihan Olahraga Pelajar Daerah (BPPLOP) Jawa Tengah, Wisma Klub Atletik dan Renang FIK Universitas Negeri Semarang (UNNES) dan Wisma Klub Atletik Salatiga. Pengambilan data berlangsung dari bulan Mei hingga Juni tahun 2019. Desain penelitian yaitu cross-sectional dengan subjek yang dipilih menggunakan teknik consecutive sampling sesuai kriteria inklusi.(Sastroasmoro \& Ismael, 2011) Perhitungan besar sampel penelitian menggunakan rumus besar sampel tunggal untuk perkiraan rerata dan diperoleh subjek sebesar 54 atlet putri, yang dikelompokan menjadi 3 kelompok terdiri dari cabang olahraga endurance $(\mathrm{n}=23)$, kekuatan $(\mathrm{n}=14)$, dan beregu $(\mathrm{n}=17)$. Cabang olahraga endurance terdiri dari olahraga maraton $(n=2)$, lari jarak menengah $(n=7)$, renang $(n=12)$, dayung $(n=2)$. Cabang olahraga kekuatan terdiri dari olahraga judo $(n=2)$, angkat besi $(n=4)$, tinju $(n=3)$, lempar lembing $(n=3)$, lempar cakram $(n=1)$, tolak peluru $(n=1)$. Cabang olahraga beregu terdiri dari olahraga voli $(n=9)$, voli pantai $(n=3)$ dan sepak takraw $(\mathrm{n}=5)$.

Subjek adalah atlet putri berusia 13-21 tahun yang tercatat sebagai atlet di Balai Pemusatan Pendidikan dan Latihan Olahraga Pelajar Daerah (BPPLOP) Jawa Tengah, Klub Atletik dan Renang FIK Universitas Negeri Semarang (UNNES) dan Klub Atletik Salatiga. Dengan kriteria inklusi diantaranya: sudah menstruasi, tidak mengkonsumsi obat-obatan yang mengandung kortikosteroid, glukokortikoid dan diuretik, tidak merokok, tidak mengkonsumsi alkohol, tidak mengkonsumsi minuman yang mengandung kafein berlebih seperti: kopi, teh, coklat, minuman berenergi, minuman bersoda ( $\geq 3$ cangkir/ hari atau $\geq 300 \mathrm{mg}$ / hari ), bersedia menjadi subjek penelitian, menandatangani inform consent dan tidak memiliki riwayat patah tulang serta gangguan penyakit tulang lain.

Pengambilan data profil antropometri yang terdiri dari persen lemak tubuh dan IMT/U. Pengukuran persen lemak tubuh, berat badan, fat free mass dilakukan menggunakan Total Body Composition Analyzer Tanita TBF-400 metode bioelectrical impedance analysis (BIA). Persen lemak dianggap underfat jika $\leq 15 \%$, normal jika 16-29 \%, overfat jika 30-34\% dan obesitas jika >35\%.(McCarthy et al., 2006) Indeks masa tubuh menurut umur (IMT/U) dilakukan dengan pengukuran berat badan dan tinggi badan menggunakan microtoise dengan batas ukur $200 \mathrm{~cm}$ dan ketelitian $0,1 \mathrm{~cm}$. Subjek berusia 13-18 tahun dilakukan pengukuran profil antropometri berdasarkan IMT/U dianggap sangat kurus jika z-score <-3 SD, kurus jika z-score <- 2SD sampai -3 SD, normal jika Z -score -2 SD sampai 1 SD, overweight jika z-score $>1$ SD sampai 2 SD dan obesitas jika z-score > 2 SD.(World Health Organization, 2007) Pada subjek yang berusia 20-21 tahun dilakukan pengukuran IMT. IMT dianggap underweight jika $<18,5 \mathrm{~kg} / \mathrm{m}^{2}$, normal jika $18,5-22,9 \mathrm{~kg} / \mathrm{m}^{2}$, overweight jika $23-24,9 \mathrm{~kg} / \mathrm{m}^{2}$, obesitas jika $\geq 25 \mathrm{~kg} / \mathrm{m}^{2}$ (World Health Organization, 2006).

Ketersediaan energi didapatkan dari selisih asupan energi dengan pengeluaran energi olahraga dibagi fat free mass (Logue et al., 2018). Asupan energi dilihat dengan metode wawancara 24 hour-food recall sebanyak 3 kali ( 2 hari biasa dan 1 hari libur) menggunakan media food photograph, dan pengeluaran energi berolahraga dilihat dengan metode wawancara 24-hour Physical Activity Record yang dilakukan sebanyak 3 kali (2 hari biasa dan 1 hari libur) kemudian dihitung menggunakan rumus 3,5 $\mathrm{x}$ Berat Badan x 5/1000 x Kelipatan Energi Metabolisme Basal (EMB) x waktu (Setyarsih et al., 2017). Ketersediaan energi dianggap lebih jika $>45 \mathrm{kkal} / \mathrm{kg}$ FFM/hari, normal jika $45 \mathrm{kkal} / \mathrm{kg} \mathrm{FFM} / \mathrm{hari}$, cukup jika 30-45 kkal/kg FFM/hari, rendah jika < $30 \mathrm{kkal} / \mathrm{kg}$ FFM/hari (Melin et al., 2019). 
Pengukuran kepadatan tulang dilakukan menggunakan quantitative ultrasound bone densitometer sonost 3000. Alat ini memiliki kecepatan suara (SOS) presisi dan akurasi 0,01. Kepadatan tulang dianggap normal jika $t$-score $\geq-1 \mathrm{SD}$, osteopenia jika $t$-score $-1 \mathrm{SD}$ sampai - 2,5 SD, osteoporosis jika $t$ score $\leq-2,5 \mathrm{SD}$ dan osteoporosis berat jika $t$-score $\leq-2,5 \mathrm{SD}$ dengan riwayat fraktur (MacKnight, 2017). Analisis perbedaan IMT, persen lemak, ketersedian energi dan kepadatan tulang dilakukan pada tiga kelompok subjek yaitu atlet cabang olahraga endurance, kekuatan dan beregu, menggunakan uji One-way ANOVA dan uji Kruskal Wallis. Penelitian ini telah mendapatkan ijin Komisi Etik Fakultas Kedokteran Universitas Diponegoro No. 305/EC/KEPK/FK UNDIP/VII/2019.

\section{HASIL DAN PEMBAHASAN}

Sebesar 74\% subjek penelititan berusia 13-18 tahun. Berdasarkan z-skor IMT/U subjek tergolong overweight sebanyak 9,3\%, obesitas sebanyak 1,9\%, sedangkan berdasarkan IMT sebanyak $13 \%$ subjek tergolong overweight dan 14,8\% tergolong obesitas. Sebanyak 22,2\% subjek memiliki persen lemak overfat dan sebanyak 9,3\% tergolong obesitas. Mayoritas ketersedian energi subjek tergolong rendah sebanyak $98,1 \%$ dan hanya cabang olahraga angkat besi yang tergolong cukup sebesar 1,9\%. Kepadatan tulang semua subjek tergolong normal, namun terdapat $12,9 \%$ yang memiliki nilai kepadatan tulang dengan $t$-score negatif, yaitu pada cabang olahraga endurance seperti renang 3 subjek $(5,5 \%)$ lari jarak menengah 1 subjek $(1,8 \%)$ dan maraton 1 subjek $(1,8 \%)$. Selain itu pada cabang olahraga kekuatan seperti tinju 1 subjek (1,8\%) serta lempar lembing 1 subjek (1,8\%). Gambaran karakteristik subjek penelitian dapat dilihat di Tabel 1.

Tabel 1. Karakteristik Subjek Penelitian

\begin{tabular}{|c|c|c|c|c|c|}
\hline Karakteristik & $\mathrm{n}$ & $\%$ & Min & Max & Median/Rerata \pm SD \\
\hline Usia & & & 13 & 21 & $16^{\mathrm{a}}$ \\
\hline 13-18 tahun & 38 & 70,4 & & & \\
\hline $19-21$ tahun & 16 & 29,6 & & & \\
\hline \multicolumn{6}{|l|}{ Cabang olahraga } \\
\hline \multicolumn{6}{|l|}{ Endurance } \\
\hline - Dayung & 2 & 3,7 & & & \\
\hline - Renang & 12 & 22,2 & & & \\
\hline - Lari jarak menengah & 7 & 13 & & & \\
\hline - Marathon & 2 & 3,7 & & & \\
\hline \multicolumn{6}{|l|}{ Kekuatan } \\
\hline - Judo & 2 & 3,7 & & & \\
\hline - $\quad$ Angkat besi & 4 & 7,4 & & & \\
\hline - Tinju & 3 & 5,6 & & & \\
\hline - Lempar lembing & 3 & 5,6 & & & \\
\hline - Lempar cakram & 1 & 1,9 & & & \\
\hline - Tolak peluru & 1 & 1,9 & & & \\
\hline \multicolumn{6}{|l|}{ Beregu } \\
\hline - Voli & 9 & 16,7 & & & \\
\hline - Voli pantai & 3 & 5,6 & & & \\
\hline - Sepak takraw & 5 & 9,3 & & & \\
\hline \multicolumn{6}{|c|}{ Status Gizi (World Health Organization, 2006, 2007) } \\
\hline Normal & 44 & 81,4 & & & \\
\hline Overweight & 6 & 11,1 & & & \\
\hline Obesitas & 4 & 7,4 & & & \\
\hline Persen lemak tubuh (McCarthy et al., 2006) & & & 16 & 49,8 & $27,38 \pm 6,28^{b}$ \\
\hline Normal & 37 & 68,5 & & & \\
\hline Overfat & 12 & 22,2 & & & \\
\hline Obesitas & 5 & 9,3 & & & \\
\hline Ketersediaan energi (Melin et al., 2019) & & & 18,6 & 38,2 & $25,6^{\mathrm{a}}$ \\
\hline Cukup & 1 & 1,9 & & & \\
\hline Rendah & 53 & 98,1 & & & \\
\hline Kepadatan tulang (MacKnight, 2017) & & & $-0,5$ & 2,6 & $0,9 \pm 0,85^{\mathrm{b}}$ \\
\hline Normal & 54 & 100 & & & \\
\hline
\end{tabular}

${ }^{\mathrm{a}}$ Median, ${ }^{\mathrm{b}}$ Rerata \pm SD 
Periode usia 12-21 tahun merupakan periode kehidupan remaja (Chapman-Novakofski, 2017). Masa remaja merupakan salah satu transisi dalam rentang kehidupan yang ditandai oleh pertumbuhan fisik yang cepat, perubahan komposisi tubuh, fisiologi, dan endokrin secara biologis, emosional, sosial dan perubahan kognitif (Jodhun et al., 2016). Berdasarkan karakteristik subjek penelitian, sebagian besar subjek berusia 13-18 tahun. Rerata usia subjek penelitian ini adalah 16 tahun yang merupakan remaja putri. Pada remaja putri peningkatan kepadatan tulang yang cepat terjadi pada usia 13-17 tahun dan menurun setelah itu. Masa remaja terjadi growth spurt yaitu puncak pertumbuhan tinggi badan, berat badan dan pertumbuhan masa tulang (peak bone mass/PMB). Pembentukan tulang paling cepat terjadi pada usia pubertas, ketika tulang menjadi semakin besar, panjang, tebal dan padat yang akan mencapai puncaknya pada usia 30 tahun, pertumbuhan yang pesat dan masa pubertas pada remaja tergantung pada berat badan dan komposisi tubuh seseorang (Dieny, 2014; Tarwoto et al., 2010).

\section{Perbedaan Indeks Massa Tubuh (IMT) Berdasarkan Cabang Olahraga}

Nilai median IMT cabang olahraga endurance yaitu $20,6 \mathrm{~kg} / \mathrm{m}^{2}$ lebih rendah dibandingkan cabang olahraga kekuatan sebesar $23 \mathrm{~kg} / \mathrm{m}^{2}$ dan cabang olahraga beregu sebesar $22,5 \mathrm{~kg} / \mathrm{m}^{2}$. Cabang olahraga kekuatan IMT tergolong overweight, dan cabang olahraga endurance serta beregu tergolong normal.

Tabel 2. Perbedaan Indeks Massa Tubuh (IMT) Berdasarkan Cabang Olahraga

\begin{tabular}{|c|c|c|c|c|c|}
\hline \multirow{2}{*}{ Cabang Olahraga } & \multirow{2}{*}{$\mathrm{n}$} & \multicolumn{3}{|c|}{ IMT $\left(\mathrm{kg} / \mathrm{m}^{2}\right)$} & \multirow[b]{2}{*}{$\mathrm{p}$} \\
\hline & & Min & Max & Median & \\
\hline Endurance & 23 & 17,8 & 30,7 & 20,6 & \\
\hline Kekuatan & 14 & 19,5 & 33,2 & 23 & $0,106^{\mathrm{a}}$ \\
\hline Beregu & 17 & 16,9 & 24,9 & 22,5 & \\
\hline
\end{tabular}

${ }^{a}$ Uji Kruskal-Wallis.

Profil antropometri berdasarkan IMT/U menunjukan sebesar 59,3\% memiliki IMT/U tergolong normal, namun terdapat satu subjek pada cabang olahraga kekuatan (tolak peluru) tergolong obesitas. Hal ini sesuai dengan penelitian di Indonesia yang menunjukan bahwa faktor asupan makan dan program latihan pada atlet tolak peluru diduga menjadi faktor IMT/U tergolong obesitas. Atlet tolak peluru merupakan atlet yang lebih menekankan kekuatan otot lengan untuk mendapatkan hasil terbaik saat bertanding, di samping itu bentuk tubuh pada atlet tolak peluru cenderung lebih besar dibandingkan atlet cabang olahraga lain. Peningkatan massa otot dan massa bebas lemak dapat meningkatkan performa lemparan atlet (Amrinanto, 2016).

Penelitian ini menunjukan tidak terdapat perbedaan IMT antara cabang olahraga endurance, kekuatan maupun beregu. Hasil analisis menunjukan median IMT cabang olahraga endurance $\left(20,6 \mathrm{~kg} / \mathrm{m}^{2}\right)$ lebih rendah dibandingkan cabang olahraga kekuatan $\left(23 \mathrm{~kg} / \mathrm{m}^{2}\right)$ dan beregu $\left(22,5 \mathrm{~kg} / \mathrm{m}^{2}\right)$, serta tergolong normal, namun pada cabang olahraga kekuatan IMT tergolong overweight. Beberapa penelitian menunjukan bahwa IMT pada cabang olahraga endurance (renang) rata-rata sebesar $21,6 \mathrm{~kg} / \mathrm{m}^{2}$ lebih rendah dibandingkan cabang olahraga kekuatan (judo) sebesar $22,4 \mathrm{~kg} / \mathrm{m}^{2}$, namun cabang olahraga endurance memiliki IMT sama dengan cabang olahraga beregu (voli dan voli pantai) sebesar $21 \mathrm{~kg} / \mathrm{m}^{2}$ dan 21,6 kg/m² (Becerra et al., 2018; Carbuhn et al., 2010; Nikolaidis, 2013). Hasil penelitian ini sejalan dengan penelitian di Indonesia yang menunjukan bahwa cabang olahraga kekuatan (atletik) 52,6\% dan cabang olahraga endurance (renang) 82,4\% memiliki IMT/U tergolong normal (Amrinanto, 2016).

Faktor yang menyebabkan IMT subjek penelitian tidak ada perbedaan yang signifikan, karena di duga jenis makanan yang disediakan oleh pihak asrama sama antar cabang olahraga, sehingga secara tidak langsung jenis makanan yang dikonsumsi antara atlet tidaklah berbeda, meskipun jumlah makanan yang dikonsumsi setiap atlet berbeda. Selain itu faktor jenis aktifitas fisik yang mayoritas sama antara atlet cabang olahraga endurance, kekuatan dan beregu dengan durasi latihan kurang lebih 3-4 jam per hari. IMT atau IMT/U merupakan salah satu cara untuk menentukan status gizi pada atlet. Status gizi dipengaruhi oleh dua faktor, yaitu faktor langsung dan faktor tidak langsung. Asupan makanan dan keadaan kesehatan merupakan faktor langsung yang mempengaruhi status gizi, sedangkan faktor tidak langsung antara lain status ekonomi, sosial dan budaya, lingkungan serta pengetahuan gizi (Amrinanto, 2016). Cabang olahraga kekuatan memiliki IMT cenderung tergolong overweight, hal ini diduga karena program latihan pada cabang olahraga ini yang cenderung mengutamakan kekuatan otot, dan faktor asupan makan yang cenderung berbeda di bandingkan cabang olahraga lainya, karena asupan energi jauh lebih tinggi dibandingkan cabang olahraga endurance dan beregu. 
Hasil penelitian ini menunjukan IMT tertinggi berada pada cabang olahraga kekuatan (tolak peluru) yaitu sebesar $33,2 \mathrm{~kg} / \mathrm{m}^{2}$ dan tergolong obesitas. Selain itu pada cabang olahraga kekuatan terdapat 3 atlet angkat besi tergolong obesitas berdasarkan IMT. Hasil tersebut sesuai dengan penelitian pada atlet KONI Provinsi Riau tahun 2015 yang menunjukkan 3 atlet $(33,3 \%)$ tergolong overweight dan 2 atlet $(22,2 \%)$ tergolong obesitas. Hal ini karena pada atlet yang memiliki IMT di atas normal faktor yang menyebabkan tidak hanya dari lemak tubuh yang berlebihan tetapi juga karena massa otot yang besar, sehingga atlet tersebut tidak dapat diklasifikasikan memiliki masalah berat badan (Latni G et al., 2015). Berdasarkan hasil wawancara mengenai asupan energi, mayoritas atlet tidak mengetahui kebutuhan asupan energi yang seharusnya dikonsumsi, walaupun dari pihak asrama sudah menyediakan siklus menu sesuai kebutuhan, namun masih banyak atlet yang mengkonsumsi makanan sesuai keinginan dan selera. Bahkan tidak hanya atlet angkat besi saja, mayoritas atlet pada cabang olahraga endurance dan beregu juga mengkonsumsi makanan dari luar asrama sesuai selera atau kesukaannya. Begitu juga dengan beberapa atlet renang dan atletik yang tidak tinggal di asrama juga tidak memperhatikan asupan makan sesuai kebutuhanya, sehingga hal tersebut dapat menyebabkan atlet tersebut memiliki IMT berlebih karena tidak adanya monitoring mengenai asupan makan yang sesuai (Latni G et al., 2015).

\section{Perbedaan Persen Lemak Tubuh Berdasarkan Cabang Olahraga}

Nilai rerata persen lemak tubuh cabang olahraga endurance sebesar 25,88 $\pm 6,23 \%$ lebih rendah

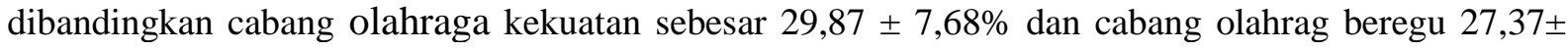
$4,57 \%$. Persen lemak tubuh cabang olahraga endurance, kekuatan dan beregu tergolong normal.

Tabel 3. Perbedaan Persen Lemak Tubuh Berdasarkan Cabang Olahraga

\begin{tabular}{lcccrc}
\hline \multirow{2}{*}{ Cabang Olahraga } & \multicolumn{5}{c}{ Kepadatan tulang } \\
\cline { 2 - 6 } & $\mathrm{n}$ & Min & Max & Rerata \pm SD & p \\
\hline Endurance & 23 & 17,2 & 40,7 & $25,88 \pm 6,23$ & $0,175^{\text {a }}$ \\
Kekuatan & 14 & 18,4 & 49,8 & $29,87 \pm 7,68$ & \\
Beregu & 17 & 16 & 33,5 & $27,37 \pm 4,57$ & \\
\hline
\end{tabular}

aji one-way anova.

Penelitian ini menunjukan tidak terdapat perbedaan persen lemak antara cabang olahraga endurance, kekuatan maupun beregu. Hasil analisis menunjukan rerata persen lemak cabang olahraga endurance $25,88 \%$ lebih rendah dibandingkan cabang olahraga kekuatan sebesar 29,87\% dan cabang olahraga beregu 27,37\% serta tergolong normal. Hal ini sejalan dengan penelitian di Amerika yang menunjukan bahwa persen lemak atlet perempuan tergolong normal, dan hanya ada beberapa cabang olahraga kekuatan seperti tolak peluru, lempar lembing, lempar cakram, yang memiliki persen lemak lebih tinggi dibandingkan atlet cabang olahraga lain. Persen lemak yang bervariasi pada atlet dipengaruhi oleh pertumbuhan, maturation, diet dan latihan yang sistematis (Malina \& Geithner, 2011).

Penelitian lain juga menunjukan persen lemak tergolong normal pada cabang olahraga endurance (renang) berkisar 21-31\%, cabang olahraga beregu (voli) sebesar 23,9\%, cabang olahraga kekuatan (tolak peluru) sebesar 31,6\% cenderung obesitas, hal ini karena faktor asupan makan tinggi energi, lemak dan protein pada cabang olahraga kekuatan dan program latihan yang didominasi angkat beban/ fitness yang dilakukan atlet tersebut. Hal ini sejalan dengan hasil penelitian yang menunjukan persen lemak subjek tertinggi berada pada cabang olahraga kekuatan (tolak peluru) yaitu sebesar $49,8 \%$ dan tergolong obesitas (Amrinanto, 2016; Nikolaidis, 2013).

Cabang olahraga kekuatan lainya seperti angkat besi sebesar $21,4 \%$ tergolong overfat dan 7,1\% tergolong obesitas berdasarkan persen lemak. Hasil penelitian serupa di Indonesia pada cabang olahraga kekuatan menunjukan seluruh atlet angkat berat, 77,8 angkat besi dan $80 \%$ binaraga mengalami obesitas berdasarkan persen lemak tubuh (Latni G et al., 2015). Atlet cabang olahraga kekuatan (angkat besi, angkat berat dan binaraga) membutuhkan tenaga yang lebih besar dibandingkan atlet lain (Haryanto, 2006). Massa otot yang besar menjadi modal utama pada atlet angkat besi dalam pertandingan karena kekuatan daya tahan otot digunakan untuk mengangkat beban seberat-beratnya, sehingga menggunakan lemak sebagai sumber energi utama, lemak dalam bentuk trigliserida akan tersimpan dalam jumlah yang terbatas pada jaringan otot dan akan tersimpan dalam jumlah yang cukup besar pada jaringan adiposa. Saat berolahraga, trigliserida yang tersimpan akan terhidrolisis menjadi gliserol dan asam lemak bebas (free fatty acid/FFA) untuk kemudian menghasilkan energi. Sehingga simpanan glikogen yang cukup dari olahan karbohidrat maupun lemak penting bagi atlet, apabila simpanan glikogen tidak mencukupi 
maka dalam menjalankan latihan atau pertandingan atlet akan cepat merasa lelah sehingga mengakibatkan terjadinya penurunan performa olahraga (Latni G et al., 2015; Minigh, 2007).

\section{Perbedaan Ketersediaan Energi Berdasarkan Cabang Olahraga}

Nilai median ketersedian energi cabang olahraga endurance yaitu $17,8 \mathrm{kkal} / \mathrm{kg}$ FFM lebih rendah dibandingkan cabang olahraga kekuatan sebesar 29,4 kkal/kg FFM, dan cabang olahraga beregu sebesar $22,3 \mathrm{kkal} / \mathrm{kg}$ FFM. Berdasarkan nilai median, nilai ketersediaan energi cabang olahraga baik endurance, kekuatan dan beregu tergolong masih rendah.

Tabel 4. Perbedaan Ketersediaan Energi Berdasarkan Cabang Olahraga

\begin{tabular}{lccccc}
\hline \multirow{2}{*}{ Cabang Olahraga } & \multirow{2}{*}{$\mathrm{n}$} & \multicolumn{3}{c}{ Ketersediaan Energi (kkal/kg FFM) } & \multirow{2}{*}{$\mathrm{p}$} \\
\cline { 3 - 5 } & 23 & 18,6 & 26,5 & Median & \\
\hline Endurance & 14 & 26 & 38,2 & $17,8^{\mathrm{a}}$ & \multirow{2}{*}{$0,033^{*}$} \\
Kekuatan & 17 & 19,1 & 29,7 & $29,4^{\mathrm{b}}$ & \\
Beregu & 17 & $22,3^{\mathrm{a}, \mathrm{b}}$ & \\
\hline
\end{tabular}

*significant uji Kruskal-Wallis. ${ }^{\mathrm{a}, \mathrm{b}}$ Uji post hoc Mann-Whitney: Endurance VS Kekuatan $\mathrm{p}=0,016$

Ketersedian energi mayoritas subjek tergolong rendah dengan nilai median pada ketiga kelompok kurang dari $30 \mathrm{kkal} / \mathrm{kg}$ FFM. Sebesar 1,9\% cabang olahraga kekuatan (angkat besi) memiliki ketersediaan energi cukup. Ketersediaan energi yang rendah dapat terjadi karena pengeluaran energi meningkat dibandingkan asupan energi, seperti terjadi pada cabang olahraga endurance, tetapi dapat juga terjadi ketika asupan energi kurang dibandingkan pengeluaran energi olahraga (Márquez \& Molinero, 2013). Mayoritas subjek dalam penelitian ini memiliki jumlah asupan energi tidak jauh berbeda dengan pengeluaran energi, bahkan ada beberapa atlet yang jumlah asupan energi lebih rendah dibandingkan pengeluaran energinya, sehingga hal tersebut membuat ketersediaan energi pada ketiga cabang olahraga tersebut tergolong rendah. Dalam penelitian ini juga menunjukan beberapa atlet yang memiliki persen lemak tergolong obesitas tetapi ketersediaan energi rendah ada pada cabang olahraga endurance (renang) sebesar 3,7\% dan kekuatan seperti angkat besi sebesar 1,8\%, lempar lembing sebesar 1,8\% dan tolak peluru sebesar $1,8 \%$. Hal ini karena asupan energi pada atlet renang dan lempar lembing memiliki asupan energi lebih rendah dibandingkan pengeluaran energi, sedangkan pada atlet angkat besi dan tolak peluru sebaliknya.

Penelitian ini menunjukan terdapat perbedaan ketersedian energi antara cabang olahraga endurance dan kekuatan dengan nilai $\mathrm{p}=0,016$. Penelitian di Amerika menyebutkan banyaknya atlet maraton dan atlet endurance lainya mengurangi ketersediaan energi karena beberapa alasan diantaranya sengaja menurunkan berat badan dan komposisi tubuh untuk meningkatkan performa, gangguan makanan dan tidak adanya dorongan biologis untuk menyeimbangkan asupan energi dengan pengeluaran energi akibat olahraga (Anne, 2007). Berdasarkan hasil wawancara mayoritas atlet pada cabang olahraga endurance sengaja membatasi asupan energi untuk menurunkan berat badan dan komposisi tubuh untuk meningkatkan performa serta tuntutan pertandingan. Faktor ini yang menyebabkan mayoritas atlet pada cabang olahraga endurance memiliki ketersediaan energi yang paling rendah, dibandingkan cabang olahraga kekuatan yang cenderung memiliki ketersediaan energi lebih tinggi. Pada cabang olahraga kekuatan cenderung memiliki asupan energi lebih tinggi dikarenakan faktor asupan makan lebih besar di bandingkan cabang olahraga lainya,

Median ketersediaan energi cabang olahraga endurance yaitu $17,8 \mathrm{kkal} / \mathrm{kg}$ FFM, lebih rendah dibandingkan dua kelompok lainya yaitu cabang olahraga kekuatan sebesar 29,4 kkal/kg FFM, dan cabang olahraga beregu sebesar $22,3 \mathrm{kkal} / \mathrm{kg}$ FFM. Hasil ini tidak jauh berbeda dari penelitian di Jerman yang menunjukan bahwa ketersedian energi cabang olahraga endurance dan beregu tergolong rendah yaitu cabang olahraga endurance sebesar 29,2 kkal/kg FFM dan cabang olahraga beregu sebesar 28,6 $\mathrm{kkal} / \mathrm{kg}$ FFM (Koehler et al., 2013). Penelitian di Singapura dan Jerman juga menunjukkan ketersediaan energi atlet cabang olahraga endurance seperti lari jarak jauh sebesar 26,8 kkal/kg FFM dan dayung sebesar 23,7 kkal/kg FFM yang tergolong rendah (Koehler et al., 2013; Ong \& Brownlee, 2017). Rendahnya ketersediaan energi pada atlet cabang olahraga endurance dibandingkan cabang olahraga lainya karena faktor beban latihan harian yang tinggi, seperti banyaknya program latihan ketahanan, di samping itu tuntutan pada cabang olahraga endurance untuk selalu memiliki bentuk tubuh yang ramping atau kurus untuk peningkatan performa, sehinga faktor penyebab rendahnya ketersediaan energi terjadi karena rendahnya asupan energi atau peningkatan beban latihan (Slater \& Lachlan, 2019). 
Komponen ketersediaan energi (asupan energi dan pengeluaran energi) menunjukan hasil lebih rendah dikarenakan asupan energi mayoritas subjek penelitian tidak sesuai kebutuhan yang sudah ditentukan dalam siklus menu oleh pihak asrama, yang seharusnya asupan energi sehari mencapai 5600 $\mathrm{kkal} / \mathrm{hari}$ yang terbagi menjadi $3 \mathrm{x}$ snack dan $3 \mathrm{x}$ makan utama, tetapi dari hasil wawancara menunjukan asupan energi dan pegeluaran energi mayoritas subjek sebesar 79,6\% dalam rentang 1000-2500 kkal. Asupan energi dengan nilai median $1773 \mathrm{kkal} / \mathrm{hari}$, sedangkan pengeluaran energi sebesar 1687,6 kkal/ hari. Pada beberapa subjek yang tidak tinggal diasrama juga menunjukan hasil yang serupa pada asupan energi. Hal ini dikarenakan beberapa subjek tersebut merupakan mahasiswa dan dalam konsumsi makan sehari-hari tidak ada yang menyediakan seperti pihak asrama, dan pola makan subjek tersebut $2 x /$ hari.

Ketersediaan energi yang rendah pada atlet terjadi melalui mekanisme fisiologis yang akan mengurangi jumlah energi yang digunakan untuk pemeliharaan seluler, termogulasi, pertumbuhan dan reproduksi (Nattiv et al., 2007) Pada individu yang sehat, keseimbangan energi dapat dicapai ketika ketersediaan energi sekitar $45 \mathrm{kkal} / \mathrm{kg}$ FFM. Ketika ketersediaan energi di bawah $30 \mathrm{kkal} / \mathrm{kg}$ FFM maka akan meningkatkan bone resorption dan menurunkan bone formation. Selain itu juga akan terjadi penurunan fungsi reproduksi sehingga meningkatkan untuk mengembalikan keseimbangan yang berakibat pada gangguan kesehatan reproduksi dan tulang (Ahmad et al., 2018; Márquez \& Molinero, 2013). Penurunan ketersediaan energi dari $45 \mathrm{kkal} / \mathrm{kg}$ FFM ke $30 \mathrm{kkal} / \mathrm{kg}$ FFM dapat menurunkan pulsasi luteinizing hormone (LH). Defisiensi energi juga dapat menekan gonadotropin releasing hormone $(\mathrm{GnRH})$ dari hipotalamus sehingga menghambat sekresi luteinizing hormone $(\mathrm{LH})$ dan follicle stimulating hormone (FSH) dari kelenjar pituitari yang kemudian menghambat stimulasi ovarium dan menurunkan produksi estrogen dan progresteron yang berpengaruh pada kepadatan tulang (Nattiv et al., 2007). Rendahnya ketersedian energi dan pembatasan energi juga dapat menyebabkan kekurangan asupan zat gizi seperti asam amino esensial, asam lemak, mineral, vitamin seperti kalsium dan vitamin D, yang diperlukan untuk kesehatan tulang (Márquez \& Molinero, 2013).

\section{Perbedaan Kepadatan Tulang Berdasarkan Cabang Olahraga}

Nilai rerata $t$-score kepadatan tulang cabang olahraga kekuatan sebesar $0,76 \pm 0,84$ SD lebih rendah di bandingkan cabang olahraga endurance sebesar $0,8 \pm 0,84 \mathrm{SD}$ dan cabang olahraga beregu sebesar 1,83 \pm 0,78 SD. Kepadatan tulang ketiga cabang olahraga tersebut tergolong normal.

Tabel 5. Perbedaan Kepadatan Tulang Berdasarkan Cabang Olahraga

\begin{tabular}{|c|c|c|c|c|c|}
\hline \multirow{2}{*}{ Cabang Olahraga } & \multicolumn{5}{|c|}{ Kepadatan tulang } \\
\hline & $\mathrm{n}$ & Min & Max & Rerata \pm SD & $\mathrm{p}$ \\
\hline Endurance & 23 & $-0,5$ & 2,1 & $0,8 \pm 0,84$ & $0,054^{\mathrm{a}}$ \\
\hline Kekuatan & 14 & $-0,5$ & 2,2 & $0,76 \pm 0,84$ & \\
\hline Beregu & 17 & 0,3 & 2,6 & $1,38 \pm 0,78$ & \\
\hline
\end{tabular}

${ }^{\mathrm{a} U j \mathrm{i}}$ one-way anova.

Penelitian ini menunjukan bahwa rerata $t$-score kepadatan tulang cabang olahraga kekuatan $(0,76 \pm 0,84 \mathrm{SD})$ lebih rendah dibandingkan cabang olahraga endurance $(0,8 \pm 0,84 \mathrm{SD})$ dan beregu $(1,83 \pm 0,78 \mathrm{SD})$, dan semua subjek memiliki kepadatan tulang normal. Hal ini bertolak belakang dengan hasil beberapa penelitian yang menunjukan bahwa atlet cabang olahraga endurance (maraton, pelari jarak menengah (800 meter), sepeda, renang) memiliki kepadatan tulang lebih rendah dibandingkan atlet cabang olahraga kekuatan (atlet angkat besi, judo) dan beregu (basket, voli, sepak bola, tenis) (Hinrichs et al., 2014; Mudd et al., 2007). Olahraga kekuatan dan beregu secara signifikan dapat meningkatkan kepadatan tulang melalui pembebanan kerangka, sedangkan olahraga endurance seperti renang merupakan olahraga tidak menahan beban sehingga tidak ada dampak pembebanan langsung pada kerangka (Bellew \& Gehrig, 2006; Hinrichs et al., 2014; Ito et al., 2016; Mudd et al., 2007).

Penelitiaan di Jerman juga menyebutkan bahwa cabang olahraga kekuatan (judo dan gulat) merupakan olahraga yang memerlukan kekuatan otot yang tinggi untuk memberikan tarikan pada tulang, kekuatan reaksi tanah yang semakin kuat akan berdampak tinggi pada kerangka, gerakan khusus seperti permainan bola, melompat, sprint akan menyebabkan tekanan tinggi pada tulang, sehingga meningkatkan kepadatan tulang (Hinrichs et al., 2014). Namun dalam penelitian ini menunjukan bahwa nilai $t$ score cabang olahraga kekuatan lebih rendah dibandingkan cabang olahraga endurance, dan beregu, hal ini diduga karena kurangnya jenis latihan seperti lari, melompat, sprint pada cabang olahraga kekuatan (angkat besi, judo, lempar lembing, lempar cakram), pada cabang olahraga tersebut biasanya jenis latih- 
anya dominan pada pembentukan otot berupa fitness dan angkat beban yang dominan gerakanya fokus pada lengan dan tangan, sehingga ketika dilakukan pengukuran kepadatan tulang menggunakan tumit, menunjukan nila $t$-score lebih rendah. Mungkin jika dilakukan pengukuran kepadatan tulang seluruh tubuh akan menunjukan $t$-score kepadatan tulang lebih tinggi.

Penelitian ini menunjukan tidak terdapat perbedaan kepadatan tulang antara cabang olahraga endurance, kekuatan maupun beregu. Kepadatan tulang semua subjek tergolong normal, disebabkan karena adanya bone mechanical loading. Hasil penelitian menunjukan bahwa weight bearing exercise (latihan pembenanan tulang) seperti voli dapat meningkatkan bone mechanical loading sehingga memberikan efek postif terhadap kesehatan tulang dan memberikan respon osteogenik yang lebih baik dibandingkan dengan bersepeda, berenang dan mendayung (Scofield \& Hecht, 2012). Kepadatan tulang dapat dipengaruhi oleh kebiasaan melakukan aktifitas fisik yang menumpu berat badan. Osteosit berperan sebagai mekanoreseptor, merespon, dan mengeluarkan faktor kimia sehingga mendorong terjadinya proliferasi osteoblast pada tulang. Aktifitas fisik yang tinggi atau menggunakan berat badan sebagai tumpuan mempengaruhi stimulus osteogenik. Hal tersebut berhubungan dengan masa tulang (Saputri \& Dieny, 2012). Di samping itu aktifitas fisik juga memiliki fungsi sebagai beban mekanik yang berperan untuk menstimulasi formasi tulang sehingga mempengaruhi ukuran, bentuk dan kekuatan tulang (Alghadir et al., 2015).

Otot dan tulang akan semakin besar dan kuat karena adanya proses pertumbuhan, aktifitas fisik, dan tercukupinya asupan gizi tertentu yang mendukung kesehatan tulang seperti vitamin D dan kalsium (Isaacson \& Brotto, 2014). Mayoritas atlet cenderung memiliki massa otot lebih tinggi dibandingkan non atlet. Massa otot yang tinggi dapat meningkatkan kepadatan tulang melalui pembebanan mekanik tubuh. Densitas tulang meningkat sebagai respon adanya pembebanan fisik dan mekanis pada tulang. Pembebanan dan aktifitas fisik dibutuhkan tulang agar pembentukan tulang dapat mengimbangi kehilangan tulang yang terjadi. Kekuatan tulang dipengaruhi oleh gerakan otot secara mekanik dan faktor hormonal. Kekuatan tulang yang dihasilkan, dipengaruhi oleh banyaknya massa otot pada komposisi tubuh. Besarnya massa otot dalam tubuh dapat dicapai salah satunya dengan adanya aktifitas fisik (Dieny, 2014). Mayoritas subjek penelitian memiliki aktifitas fisik dengan tingkat instensitas latihan yang tinggi dan jenis latihan yang hampir sama, sehingga dimungkinkan memiliki beban mekanik yang besar pula. Hal inilah yang mengakibatkan t-score kepadatan tulang pada semua subjek tergolong normal.

\section{SIMPULAN}

Mayoritas atlet memiliki persen lemak tubuh, IMT, kepadatan tulang tergolong normal, dan ketersediaan energi tergolong rendah. Persen lemak tubuh dan IMT cabang olahraga endurance lebih rendah dibandingkan cabang olahraga kekuatan dan beregu. Terdapat perbedaan ketersediaan energi antara cabang olahraga endurance dan kekuatan $(p<0,05)$. T-score kepadatan tulang cabang olahraga kekuatan lebih rendah dibandingkan cabang olahraga endurance dan beregu.

\section{UCAPAN TERIMAKASIH}

Penelitian ini dibiayai oleh hibah Riset Penerapan dan Pengembangan (RPP) Fakultas Kedokteran Universitas Diponegoro tahun 2019.

\section{DAFTAR PUSTAKA}

Ahmad, N. S., Hamid, M. S. A., Cheong, J. P. G., \& Hamzah, S. H. (2018). Bone mineral density and associated risk factors among female athletes: A cross-2 sectional study. Sains Malaysiana, 47(1), 123-129. https://doi.org/10.17576/jsm-2018-4701-15

Alghadir, A. H., Gabr, S. A., \& Al-Eisa, E. (2015). Physical activity and lifestyle effects on bone mineral density among young adults: sociodemographic and biochemical analysis. Journal of Physical Therapy Science, 27(7), 2261-2270. https://doi.org/10.1589/jpts.27.2261

Amrinanto, A. H. (2016). Analisis perbedaan status gizi, persen lemak tubuh dan massa otot atlet di SMP/SMA Negeri Olah raga Ragunan Jakarta. Institut Pertanian Bogor.

Anne, L. B. (2007). Low energy availability in the marathon and other endurance sports. Sports Medicine, 37(4), 348-352. https://doi.org/10.2165/00007256-200737040-00019 
Becerra, M. O., Espina-agulló, J. J., Pueo, B., Jiménez-, J. M., Penichet-tomás, A., \& Sellés-pérez, S. (2018). Anthropometric profile and performance indicators in female elite beach handball players. Polskie Towarzystwo Antropologiczne, 2, 1155-1160. https://doi.org/10.7752/jpes.2018.s2172

Bellew, J. W., \& Gehrig, L. (2006). A comparison of bone mineral density in adolescent female swimmers, soccer players, and weight lifters. Pediatric Physical Therapy, 18(1), 19-22. https://doi.org/10.1097/01.pep.0000200952.63544.16

Braam, L. A. J. L. M., Knapen, M. H. J., Geusens, P., Brouns, F., \& Vermeer, C. (2003). Factors affecting bone loss in female endurance athletes. The American Journal of Sports Medicine, 31(6), 889-895. https://doi.org/10.1177/03635465030310062601

Carbuhn, A. F., Fernandez, T. E., Bragg, A. F., Green, J. S., \& Crouse, S. F. (2010). Sport and training influence bone and body composition in women collegiate athletes. Journal of Strength and Conditioning Research, 24(7), 1710-1717. https://doi.org/10.1519/JSC.0b013e3181d09eb3

Chapman-Novakofski, K. (2017). Nutrition and bone health. In Krause's Food \& The Nutrition Care Process (13th ed., pp. 456-467). Elsevier.

Day, J., Wengreen, H., \& Heath, E. (2016). Prevalence of low energy availability in collegiate female runners and implementation of nutrition education intervention. Sports Nutrition and Therapy, 1(1), 1-7. https://doi.org/10.4172/2473-6449.1000101

Dieny, F. F. (2014). Permasalahan gizi pada remaja putri. Graha Ilmu.

Fink, H. H., \& Mikesky, A. E. (2015). Pratical applications in sport nutrition (R. Dearborn (Ed.); 4th ed.). Jones \& Bartlett Learning.

Haryanto, B. (2006). Profil kekuatan atlet pelatihan jangka panjang (PJP) Jawa Tengah cabang olahraga angkat besi/angkat berat dan binaraga Pon XVII dari tahun 2005-2006. Universitas Negeri Semarang.

Hinrichs, T., Chae, E.-H., Lehmann, R., Allolio, B., \& Platen, P. (2014). Bone mineral density in athletes of different disciplines: A cross- sectional study. The Open Sports Sciences Journal, 3(1), 129133. https://doi.org/10.2174/1875399X010030100129

Isaacson, J., \& Brotto, M. (2014). Physiology of mechanotransduction: How do muscle and bone "talk" to one another? Clinical Reviews in Bone and Mineral Metabolism, 12(2), 77-85. https://doi.org/10.1007/s12018-013-9152-3

Ito, I. H., Mantovani, A. M., Agostinete, R. R., Costa, P., Zanuto, E. F., Christofaro, D. G. D., Ribeiro, L. P., \& Fernandes, R. A. (2016). Practice of martial arts and bone mineral density in adolescents of both sexes. Revista Paulista de Pediatria (English Edition), 34(2), 210-215. https://doi.org/10.1016/j.rppede.2015.09.003

Jodhun, B. M., Pem, D., \& Jeewon, R. (2016). A systematic review of factors affecting energy intake of adolescent girls. African Health Sciences, 16(4), 910-922. https://doi.org/10.4314/ahs.v16i4.5

Kementerian Kesehatan Republik Indonesia. (2014). Pedoman gizi olahraga prestasi. Kementerian Kesehatan Republik Indonesia.

Koehler, K., Achtzehn, S., Braun, H., Mester, J., \& Schaenzer, W. (2013). Comparison of self-reported energy availability and metabolic hormones to assess adequacy of dietary energy intake in young elite athletes. Applied Physiology, Nutrition, and Metabolism, 38(7), 725-733. https://doi.org/10.1139/apnm-2012-0373

Latni G, J., Ernalia, Y., \& Azrin, M. (2015). Gambaran status gizi atlet angkat berat, angkat besi dan binaraga Komite Olahraga Nasional Indonesia (KONI) Provinsi Riau tahun 2015. Jurnal Online Mahasiswa Universitas Riau, 33(11), 1-15. https://jom.unri.ac.id/index.php/JOMFDOK/article/view/8219

Logue, D., Madigan, S. M., Delahunt, E., Heinen, M., Mc Donnell, S.-J., \& Corish, C. A. (2018). Low energy availability in athletes: A review of prevalence, dietary patterns, physiological health, and sports performance. Sports Medicine, 48(1), 73-96. https://doi.org/10.1007/s40279-017-0790-3

MacKnight, J. M. (2017). Osteopenia and osteoporosis in female athletes. Clinics in Sports Medicine, 36(4), 687-702. https://doi.org/10.1016/j.csm.2017.05.006

Malina, R. M., \& Geithner, C. A. (2011). Body composition of young athletes. American Journal of Lifestyle Medicine, 5(3), 262-278. https://doi.org/10.1177/1559827610392493 
Márquez, S., \& Molinero, O. (2013). Energy availability, menstrual dysfunction and bone health in sports; an overwiew of the female athlete triad. Nutricion Hospitalaria, 28(4), 1010-1017. https://doi.org/10.3305/nh.2013.28.4.6542

McCarthy, H. D., Cole, T. J., Fry, T., Jebb, S. A., \& Prentice, A. M. (2006). Body fat reference curves for children. International Journal of Obesity, 30(4), 598-602. https://doi.org/10.1038/sj.ijo.0803232

Melin, A. K., Heikura, I. A., Tenforde, A., \& Mountjoy, M. (2019). Energy availability in athletics: Health, performance, and physique. International Journal of Sport Nutrition and Exercise Metabolism, 29(2), 152-164. https://doi.org/10.1123/ijsnem.2018-0201

Minigh, J. L. (2007). Sport medicine (health and medical issue today). Greenwood.

Mudd, L. M., Fornetti, W., \& Pivarnik, J. M. (2007). Bone mineral density in collegiate female athletes: Comparisons among sports. Journal of Athletic Training, 42(3), 403-408. https://europepmc.org/article/med/18059997

Muth, N. D., \& Zive, M. M. (2019). Sports nutrition for health professionals. F.A. Davis Company.

Nattiv, A., Loucks, A., Manore, M., Sanborn, C., Sundgot-Borgen, J., Warren, M., \& American College of Sports Medicine. (2007). American College of Sports Medicine position stand. The female athlete triad. Medicine \& Science in Sports \& Exercise, 39(10), 1867-1882. https://doi.org/10.1249/mss.0b013e318149f111

Nikolaidis, P. T. (2013). Body mass index and body fat percentage are associated with decreased physical fitness inadolscent and adult fermale volleyball players. Journalof Research in Medical Sciences, 18(1), 22-26.

Nose-Ogura, S., Yoshino, O., Dohi, M., Kigawa, M., Harada, M., Kawahara, T., Osuga, Y., \& Saito, S. (2018). Low bone mineral density in elite female athletes with a history of secondary amenorrhea in their teens. Clinical Journal of Sport Medicine, Publish Ah, 1-6. https://doi.org/10.1097/JSM.0000000000000571

Ong, J. L., \& Brownlee, L. A. (2017). Energy expenditure, availability, and dietary intake assessment in competitive female dragon boat athletes. Sports, 5(2), 45. https://doi.org/10.3390/sports5020045

Saputri, G. A. R. R., \& Dieny, F. F. (2012). Female athlete triad pada atlet putri di pusat pendidikan latihan (Pusdiklat) Ragunan Jakarta. Journal of Nutrition College, 1(1), 405-413. https://doi.org/10.14710/jnc.v1i1.512

Sastroasmoro, S., \& Ismael, S. (2011). Dasar-dasar metodologi penelitian klinis (4th ed.). Sagung Seto.

Schtscherbyna, A., Soares, E. A., de Oliveira, F. P., \& Ribeiro, B. G. (2009). Female athlete triad in elite swimmers of the city of Rio de Janeiro, Brazil. Nutrition, 25(6), 634-639. https://doi.org/10.1016/j.nut.2008.11.029

Scofield, K. L., \& Hecht, S. (2012). Bone health in endurance athletes: Runners, cyclists, and swimmers. Current Sports Medicine Reports, 11(6), 328-334. https://doi.org/10.1249/JSR.0b013e3182779193

Setyarsih, L., Ardiaria, M., \& Fitranti, D. Y. (2017). Hubungan densitas energi dan asupan cairan dengan berat jenis urin pada remaja. Journal of Nutrition College, 6(4), 326. https://doi.org/10.14710/jnc.v6i4.18670

Slater, G., \& Lachlan, M. (2019). Strength and power athletes. In Nutrition For Sport,Exercise and Performance (p. 254). Allen \& Unwin.

Tarwoto, T., Aryani, R., Nuraenii, A., \& Miradwijaya, B. (2010). Kesehatan remaja problem dan solusinya. Salemba Medika.

World Health Organization. (2006). WHO Child Growth Standards: Methods and development Length/height-for-age, weight-for-age, weight-for-length, weight-for-height and body mass index-for-age. In World Health Organization.

World Health Organization. (2007). Growth reference data for 5-19 years. WHO. https://www.who.int/growthref/en/ 